\title{
WEICHSELGARTNER, Carolin Renate, Kloster und Stadt. Das Angerkloster in München im Mittelalter
}

\author{
Olivier Richard
}

\section{OpenEdition}

\section{Journals}

Édition électronique

URL : http://journals.openedition.org/ifha/725

DOI : $10.4000 /$ ifha. 725

ISSN : 2198-8943

Éditeur

IFRA - Institut franco-allemand (sciences historiques et sociales)

Référence électronique

Olivier Richard, « WEICHSELGARTNER, Carolin Renate, Kloster und Stadt. Das Angerkloster in München im Mittelalter », Revue de l'IFHA [En ligne], Date de recension, mis en ligne le 01 janvier 2006, consulté le 22 septembre 2020. URL : http://journals.openedition.org/ifha/725 ; DOI : https://doi.org/10.4000/ ifha. 725

Ce document a été généré automatiquement le 22 septembre 2020.

(C)IFHA 


\title{
WEICHSELGARTNER, Carolin Renate, Kloster und Stadt. Das Angerkloster in München im Mittelalter
}

\author{
Olivier Richard
}

1 Les relations entre les couvents de Frères Mendiants et les cités qui les accueillaient ont fait l'objet d'études nombreuses ; c'est moins vrai pour les couvents de clarisses ou dominicaines, souvent installés en ville, mais soumis par leur règle à la clôture. La courte thèse de doctorat de C.R.W. - 128 pages de texte - s'interroge sur les implications de cette situation paradoxale à partir de l'exemple de l'Angerkloster de Munich. Quelles étaient les relations entre cet établissement, unique couvent féminin de Munich à la fin du Moyen Âge, et son environnement urbain ? Comment le couvent clarisse devint-il un point d'intégration de la population de la ville?

C.R.W. décrit d'abord les origines du couvent de clarisses, intimement liées à l'installation dans la ville ducale des franciscains, qui, déménageant à la fin du XIIIe s., laissent leur site originel aux sœurs. Elle décline ensuite son ouvrage en trois points, le plan institutionnel - protection ducale, inscription dans l'ordre franciscain, et contrôle par les institutions urbaines -, les ressources économiques du couvent, ainsi que l'étude de la vie religieuse au service de la société urbaine. Ce dernier point est malheureusement traité très rapidement (24 pages).

3 L'ouvrage se présente comme une monographie d'histoire locale, renonçant notamment à toute dimension comparative. Il sera donc utile aux chercheuses et chercheurs s'intéressant à Munich (cf. les listes de membres du couvent en annexe) plus qu'à celles et ceux qui chercheraient des idées originales sur les rapports entre les établissements ecclésiastiques et les villes.

4 Olivier RICHARD (Université Marc-Bloch - Strasbourg II) 